\title{
Student Perceptions of Literacy after the Ontario Secondary Literacy Course: A Qualitative Inquiry
}

\author{
Lianne Van De Wal \\ Nipissing-Parry Sound Catholic District School Board
}

\section{Thomas G. Ryan}

Nipissing University

\begin{abstract}
Adolescent literacy has emerged via the high-stakes standardized test known as the Ontario Secondary School Literacy Test (OSSLT) as a critical area of debate and study. Research has indicated a direct connection between literacy and identity, and that student literacy practices differ from traditional measures of literacy located in school curriculum and evaluated via standardized tests such as the OSSLT. Outcomes such as limited achievement, difficulties with literacy and the development of literacy skills, and subsequent below standard scores can diminish student self-concept, lower self-esteem, and impede self-efficacy. This ethnographic case study illuminated the impact of OSSLT and subsequent mandatory enrolment in the Ontario Secondary School Literacy Course using semi-structured interviews involving high-school students from a northern Ontario secondary school. Previous related research outcomes, which demonstrated a connection between standardized test scores and self-concept, were realized via participants' understanding and perception of literacy, and through mitigating factors impacting literacy engagement and achievement.
\end{abstract}

Keywords: Literacy, standardized testing, secondary school, failure

Lianne Van De Wal is a secondary school teacher at St. Joseph-Scollard Hall in Ontario, Canada. Her research interests include adolescent literacy, multiliteracies, and literacy and reading instruction in secondary schools. E-mail: vandewal@npsc.ca.

Thomas G. Ryan (Ed.D.) is Professor within the Schulich School of Education, Nipissing University, Ontario, Canada, where he teaches graduate studies online. As a former elementary and secondary special educator he has worked with students in all grades.

Email: thomasr@nipissingu.ca

Brock Education, 23(2), Spring 2014, pp.3-23 
Measuring secondary student literacy achievement has been a dominant educational focus since the inception and implementation of the Ontario (Canada) Secondary School Literacy Test (OSSLT) in 2002, despite the fact that standardized testing has drawn criticism from stakeholders (McNeil, 2000; Nezavdal, 2003; Ricci, 2004; Sweet, 2006). The OSSLT compartmentalizes students as "literate" and "illiterate" on the basis of being "successful" versus "unsuccessful" on a single high-stakes standardized test (EQAO, 2011). Standardizing literacy may only serve to perpetuate the idea that if a student is not successful on the test, he or she is not literate (Fairbairn \& Fox, 2009). Students, particularly those who do not find success on the test, run the risk of viewing reading and writing as a chore rather than an effective means of conveying their thoughts, feelings, and beliefs (Moon, Brighton, Jarvis, \& Hall, 2007). In Ontario, passing the OSSLT is a graduation requirement, and since 2003 an added provision of the requirement has read that students who are unsuccessful at least once and who have been eligible to write twice (or since June 2004, students who at the discretion of the school principal are deferred from writing) may enroll in the Ontario Secondary School Literacy Course (OSSLC) (Ontario Ministry of Education [OME], 2009). Essentially the OSSLT was repackaged in an instructional course framework. Passing the OSSLC (with a mark of 50\% or greater) allows students to fulfill the literacy graduation requirement for an Ontario Secondary School Diploma (OSSD).

In the OSSLC, students may enter with a negative view of their own abilities after one or more (usually two) on the OSSLT (Van De Wal, 2012). Often students enrolled in the OSSLC do not begin the course as eager students who are excited about learning; they habitually enter with negative self-image (Fairbairn \& Fox, 2009; Van De Wal, 2012). In some cases it is evident that frequent literacy testing is creating an adverse reaction to reading and literacy, and is in fact promoting, encouraging, and potentially increasing aliteracy, which is the ability to read but the desire not to (Bouchard, 2003; Johnston \& Winograd, 1985; Volante, 2006). In other cases a disconnection between school literacy and after-school literacy is overt (Alvermann, 2001; Beth, Reed, Schallert, \& Woodruff, 2004; Luttrell \& Parker, 2001; Pahl \& Rowsell, 2005).

\section{Background and Significance}

The significance of adolescent literacy and the learners' identity has been noted by many scholars (Alvermann 2001; Dillon, Moje, and O'Brien 2000; Freire and Macedo 1987; Luttrell and Parker (2001). The identification of literacy has been shown to be a powerful tool for establishing voice (Dillon et al., 2000) playing a role a role in empowering or disempowering individuals (Freire \& Macedo, 1987), and recognizing that the conventional or traditional practice of literacy that dominates school culture is, at times, at odds with the social practice of literacy (Alvermann, 2001; Luttrell \& Parker, 2001). Graham and Neu (2004) concluded that standardized tests "encourage the internalization of disciplining activities" (p. 301), or assessments of above average or below average status, and reproduce them in subsequent behaviours.

Teachers also sense the stress and pressure of the standardized testing movement and, as a result, the day-to-day classroom conduct is impacted, influenced, and changed (Moon et al., 2007; Ryan, 2003). Drawing upon Foucault's work on governmentality, Graham and Neu (2004) claim that "what gets measured gets done" [because] "the publication of the results not only informs the electorate and other audiences, but builds pressure to conform" (p. 312). This pressure provides a somewhat invisible undertow and can cause students and teachers to become

Brock Education, 23(2), Spring 2014, pp.3-23 
passive subjects rather than active agents (Moon et al., 2007). Students that internalize societal norm" and conduct themselves as passive subjects further serve to impact the identity and selfconcept of the adolescent literacy learner who is in need of an authentic and productive learning experience (Fairbairn \& Fox, 2009; Moon et al., 2007).

\section{Problem}

As more students are graduating high school with lower literacy proficiencies-25\% of students graduate with inadequate (below provincial level 3) secondary literacy skills (Maxwell, 2010) and $37.8 \%$ of adults ages 16-25 have low literacy (Statistics Canada, 2005) - secondary teachers are faced with the need to go "back to basics" and teach what may be remedial level literacy in some cases. Within the secondary school domain, the assumption that students enter high school with the ability to read and write, and that students' literacy skills will serve them well across the curriculum and in varied subject matters needs attention. Teachers need more insight to serve their students to the best of their ability (Fairbairn \& Fox, 2009), before it is too late.

Research has indicated that literacy acquisition is much more difficult once individuals leave school (Ryan \& MacGregor, 2011; Statistics Canada, 2008). If we can better understand the journey of the adolescent literacy learner in the age of the OSSLT (and the OSSLC), educators can develop their methods to strengthen and enhance not only the literacy skills of these students, but also impact self-esteem, self-concept, self-efficacy, and, in turn, their overall positive identity and productivity as contributing members of our society (Fairbairn \& Fox, 2009).

\section{Purpose}

The purpose of this research was to examine student perceptions of literacy within a secondary school while exploring literacy at this level. We determined what each student, who experienced failure with the OSSLT, identified as key factors that contributed to their views on, and definitions of literacy. Data concerning the types of literacy activities adolescent literacy learners were engaged in, and how this engagement and achievement, or lack thereof, impacted their selfconcept, was identified, gathered, examined and interpreted as part of an ethnographic case study framework.

\section{Research Questions}

Following a review of the research literature, and based upon our own teaching experience, we determined that our primary research question to guide the study (Agee, 2009) would be: What are secondary students' perceptions of literacy following the Ontario Secondary School Literacy Course?

Next we asked participants:

1. What does the term "literacy" mean to you?

2. How have your beliefs about reading and writing changed since grade 9 ? Be sure to comment on feelings after the OSSLT and OSSLC.

3. How do your in-school reading and writing practices differ from your reading and writing habits outside of school?

4. How have your experiences with literacy from grades 9-12 impacted your self-concept?

Brock Education, 23(2), Spring 2014, pp.3-23 


\section{Review of Literature}

\section{Definitions of Literacy}

Many have investigated adolescent literacy in a variety of ways, most notably from its relationship with engagement (Casey, 2008), to at-risk students (Fairbairn \& Fox, 2009; O'Brien, 1998; Taylor \& Nesheim, 2000), and best practices (Moje, Young, Readence, \& Moore, 2000). However, in order to better understand the concept of adolescent literacy, it was important to first reflect upon the multiple definitions of literacy and what it means to be "literate" from both educational and socio-cultural perspectives (Agee, 2009). Contemporary definitions of literacy stress the multiplicity of literacy behaviours, practices, and activities. Truly, what it meant to be literate a century ago - that is, having "the simple ability to read and write" (Movement for Canadian Literacy, 2005, p. 2) was a definition of literacy that many scholars (Beth et al., 2004; Brozo \& Simpson, 1991; Hinchman \& Moje, 1998; Irvin, Meltzer, \& Dukes, 2007; Kamil \& Kim, 2004; Moje et al., 2000; O’Brien, Stewart, \& Moje, 1995; Street, 1994) would deem too exclusive and one-dimensional at present.

Secondary school students' views of literacy vary from those of their parents and teachers in that they are often broader and more inclusive (Beth et al., 2004). In a review of the disconnect between adolescents' literacy practices and teachers' definitions of literacy, Beth et al. (2004), argued that the likelihood that teachers have overlooked the extension of literacy to include new literacies and those that may prove essential in students' futures is great, consistently creating traditional literacy tasks rather than challenging the scope of literacy.

While numerous and diverse definitions of "literacy" can be found in the existing body of literature (Brozo \& Simpson, 1991; Hinchman \& Moje, 1998; Irvin et al., 2007; Kamil \& Kim, 2004; O'Brien et al., 1995; Street, 1994), a productive definition that is appropriately inclusive stems from Street's (1994) qualitative research focused upon literacy practices in varied contexts from South East Asia in the 15th century to contemporary South Pacific, to more recent accounts of New Guinea and Philadelphia. Street's (1994) aim was to demonstrate "the variety and complexity of literacies" (p. 139) while locating literacy practices in the context of power and ideology rather than as a neutral and technical skill. As a result, Street (1994) composed an "ideological" model of literacy that recognizes multiple literacies by claiming, "literacy practices are constitutive of identity and of personhood" (p. 140).

\section{Adolescent Literacy and Identity}

Moje et al. (2000) defined adolescent literacy simply as the "distinctive dimensions of the reading and writing of youth" (p. 402) noting that these youth have "multiple literacies" (p. 402) that stem from changing and varied texts that have grown to include the Internet, film, music, magazines, and television among other mediums. While it is important to understand that multiple literacies exist and play an important role in the lives of today's adolescents, it is also imperative to explore the research on the role of literacy in the identity formation of youth. Freire and Macedo (1987) proposed that literacy was a set of practices that function to empower or disempower people, and according to Freire (1970) this "self-depreciation is . . characteristic of the oppressed, [deriving] from their internalization of the opinion the oppressors hold of them" (p. 49). 
Hall (2012) recognized the connection between literacy and identity and focused on finding ways to allow students to rewrite their reading identities. The objective of the study was to help "students evolve into the kinds of readers they wanted to become" (p. 368). Hall's (2012) justification for the study was the fact that "students' reading identities are created over time based on their experiences in school and their understanding of the different identities available to them" (p. 369). It was these "available identities"-_poor/struggling, average, and good/excellent" (Hall, 2012, p. 369) that prompted Hall to investigate and challenge the institutionalized norms found within schools. Hall discovered students recognized that their teachers often had expectations about their reading identities based on test scores, and they believed they "could be the kinds of readers they wanted to be when at home," as they were "generally free to simply read" (p. 371). Consequently, repeated failure, particularly failure associated with high-stakes testing, greatly reduced motivation, increased student helplessness, decreased students' self-efficacy, and greatly affected the ways in which adolescents viewed literacy as a whole (Johnston \& Winograd, 1985).

\section{Adolescent Learners' Perspective}

In seeking to illuminate student perceptions of the OSSLT, Klinger and Luce-Kapler (2007) sought to analyze perceptions of the OSSLT, focusing on three aspects of the test: students' preparation, the impact and value of the test, and the influence of test-style programs on students' views about literacy. They found that test preparation often came at the expense of their regular classroom instruction and that students responded to questions in a "formulaic" manner because of the rigid test instructions that sent a message to students that there was a right and wrong way to answer questions, further suggesting "a narrowly expressed view of literacy" ( $p$. 29 ) inherent in the test. They discovered obvious differences between the responses of successful and unsuccessful students. Participants concluded that the test "focused more on demonstrating formulaic writing structures as opposed to literacy" (p. 43). As for the impact and value of the OSSLT, researchers found that support for the test was minor with successful students, and that unsuccessful students were "almost unanimously against the OSSLT" (p. 45). Klinger and LuceKapler (2007) concluded: "The test seemed to impede students' understanding of literacy and even the importance of literacy" (p. 47).

Kearns (2011) interviewed 16 unsuccessful test takers discovering that the OSSLT caused participants to feel "shame" and marginalization due to their participation, had negative effects on their identity formation as they were "named as different, deemed not up to the standard" (para. 41), and caused them to have altered perceptions of themselves. Kearns (2011) noted that many students found their failure to be a shock, suggesting that "students who fail the literacy test have a different perception of what it means to be literate and successful than the standards upheld by this high-stakes, large-scale literacy test" (para. 40). She also found that the experience made her participants feel "degraded, humiliated, stressed, and shamed" (para. 22), even "like a loser" (para. 29). Kearns suggested "the literacy test was alienating for some youth involved in the study because it undermined some of their positive identity-confirming experiences, and forced them to negotiate a negative label" (para. 48).

Zheng, Klinger, Cheng, Fox, and Doe (2011) elected to examine the relationship between students' background, their in-and-out-of-school literacy activities, and their perception of the OSSLT through the use of a three-part questionnaire. Zheng et al. (2011) claimed that, while the "students' views of the OSSLT varied according to their group membership, those who had not

Brock Education, 23(2), Spring 2014, pp.3-23 
taken the test generally reported more positive perceptions of the OSSLT" compared to those who had not (pp. 119-120).

Reflecting upon the research to date it appeared to us that we have not heard from the student who has been deemed unsuccessful on the OSSLT and who has fully completed the OSSLC as an alternate literacy graduation requirement. However, Main's (2008) study did document the teacher's perspective and shed light on the adolescent learner through personal experiences as a teacher of the OSSLC. The researcher documented how a "notoriously rowdy" group of teens sat in the classroom on the first day of school, silent and "demoralized" (p. 47), with a "low self-concept in terms of literacy" (p. 50). Main (2008) claimed that the OSSLC, with a sound and sensitive pedagogical approach, had the ability to help adolescents form positive identities, and have positive and productive literacy experiences making meaningful and authentic connections with tasks that are inclusive of multiple types of literacies rather than restricting students to "the traditional literacies of the classroom" (p. 51). Like other researchers we concluded that the adolescent individual's perspective of literacy was underrepresented in the research literature (Jeong-Hee, 2011).

\section{Methodology}

\section{Research Mode}

This qualitative (ethnographic) investigation required daily presence at the research site (secondary school classroom) and utilized a semi-structured interview process with four participants over one full secondary level semester (Creswell, 2012). Our ethnographic inquiry provided a detailed day-to-day portrait of events and captured the culture of the students as a group with shared values, language, beliefs and goals over a period of time (Creswell, 2012, $\mathrm{p}$. 462). Creswell (2012) describes how "culture is everything having to do with human behavior and belief" (p. 462).

\section{Participant Selection}

All participants were grade 12 students between the ages of 17 and 19 who had just completed the OSSLC and failed (less than 75\% ) the OSSLT twice. As a result of the need to create a study sample that shared OSSLT failure as a defining characteristic, purposeful and homogeneous sampling (Creswell, 2008) was used to select individuals who had just completed the OSSLC, attempted the OSSLT, and received an OSSLT score of unsuccessful at least twice. Therefore, the defining characteristic of the homogenous sampling procedure was not only the defining characteristic of age, but of OSSLT failure.

\section{Data Collection}

The main method of data collection was one-on-one audio-recorded interviews. The semistructured interview format allowed for the exploration of emergent questions and topics. Additional data were gathered through field/observation notes, emails, school records, EQAO results (including OSSLT results), and Individual Education Plans (IEPs); and other documents such as participants'/students' literacy portfolios containing their work from the OSSLC and culminating tasks for the OSSLC. Fieldwork was completed during one school semester (January 
to June). Data were gathered within the OSSLC classroom setting, where the participants worked and where "shared patterns" could be studied (Creswell, 2008, p. 482).

\section{Ethical Considerations}

Creswell (2012) suggests that ethnographers should be "open and transparent about gathering data ... study people and places with respect ... [while] ensuring privacy" (p. 474). In addition, we worked to ensure that all research was conducted in accordance with the University's Research Ethics Board guidelines since we worked with human participants in the study. The second ethical consideration was confidentiality (privacy) as the anonymity of participants was paramount and led to the use of pseudonyms. Another ethical consideration that concerned the researchers were the ages of the participants (under the age of 18) that required parent or guardian consent of their son or daughter to participate in the study. The last notable ethical consideration concerned the preexisting relationships between the student participant and researcher/educator that may exist as a result of the place of employment of the educator/researcher. These existing relationships were acknowledged and respected herein.

\section{Methodological Assumptions}

The first assumption was that all students experienced difficulty with literacy to varying degrees. While it was acknowledged that all participants failed the OSSLT twice, the levels of ability among the participants varied. The second assumption was that all participants had an awareness of their literacy journey. Students did not elaborate or share as much as possible since reflection upon literacy was still emerging prior to the interview. The third assumption was that all participants could articulate and communicate their thoughts in response to the questions. Oftentimes, responses were overly concise and elaborating probes were a necessity. The fourth assumption was that all participants felt safe, comfortable, and free of judgment, and were willing to be entirely candid, open, and honest. Given that the participants were teenagers, assuming that they would feel free of judgment when they are asked to talk about literacy-something they may already be insecure about - may have been a poor assumption. Because of this, participants may have felt the need to hold back information in order to preserve their cognitive safety (self-esteem).

\section{Limitations}

Firstly, as a result of convenience sampling, generalizability was limited as these views are representative of all OSSLT student test-takers and OSSLC participants provincially. Secondly, limitations inherently exist within the qualitative form of data collection in interviews. Authenticity could be questioned. The participants' ability or desire to be less candid given the pressure of face-to-face conversation could be a factor in determining whether or not a participant was fully open and honest. Further, given that the participants characteristically have difficulty with communication, having them engage in an oral question and answer session may not have proved to garnered as much useful data as what might have been possible via another method of data collection. Another challenge posed was nervousness of the student participant. None of the participants had done any type of interview before and were nervous about the 
format. Lastly, matching the level of the questions to the ability of the informants (Creswell, 2008) was paramount with this sample group.

\section{Findings}

\section{Participants' Definition and Understanding of Liiteracy}

Early in the interview process, participants (Laura, Andrew, Scott, and Karlie) were asked to provide a definition of literacy. There was a significant amount of overlap in the participants' responses, with all students generating a very conventional or traditional definition of literacy rather than a broader or more inclusive one. Interestingly enough, there seemed to be a divide between how the students defined literacy using words and how their actions demonstrated a different and broader definition of literacy.

The first participant interviewed, Laura, was an 18-year-old girl who had been actively involved in her school's social outreach club, an extracurricular activity that focused on charity and service. She had a traditional view of literacy, with a focus on "writing, reading, understanding things" (Laura's, personal interview, June 09, 2009). Laura's definition is shared by the majority of this study's participants.

The next student interviewed in this study was Andrew. Andrew described himself as a simple, average student whose goal is to be a mechanic. When asked how he defined literacy, he stated that literacy is "your grammar, your spelling, your reading, and your level of where you are with reading" (Andrew, personal interview, June 15, 2009). Andrew, too, viewed the concept of literacy in a very traditional light by providing what is a very conventional definition of reading (syntax and comprehension). He did not view poetry as a form of literacy, and, in his opinion, reading instructions at home "on how to do something" (Andrew, personal interview, June 15, 2009), is not really literacy either.

Karlie, an outgoing yet soft-spoken young lady with a prim and proper appearance, also shared this similar, narrow, or perhaps traditional, view: "I think literacy means the ability to read and write, like their levels of reading and writing, and understanding what you're reading" (Karlie, personal interview, June 10, 2009).

Finally, Scott, at the time, Scott was a grade 12 student whose interests reflected his suburban setting and lifestyle. He enjoyed hunting and playing both school and intramural sports including football, hockey, baseball, archery, and golf. Upon graduation, Scott had decided to complete an apprenticeship in order to become a plumber. When asked what the term literacy meant to him, he simply and shortly replied, "writing, reading, [and] the meaning behind them" (Scott, personal interview, June 15, 2009).

\section{Factors Impacting Literacy Engagement and Achievement}

\section{Standardized Test Failure}

Laura described writing the OSSLT as "stressful . . pressuring . . especially the [written part]. [Writing the test] made me feel scared and nervous" (Laura, personal interview, June 10, 2009). Andrew's reaction to the test proved that, for him, it was indeed an intimidating experience. He

Brock Education, 23(2), Spring 2014, pp.3-23 
stated that he "was really nervous and I blanked out... I felt really bored. I felt like I didn't have a chance to pass it" (Andrew, personal interview, June 15, 2009). Karlie shared the same view, noting that "it was scary. I was really nervous cause like I know it's really important and it made me really nervous that it could affect whether I graduate or not" (Karlie, personal interview, June 10, 2009). She went on to say that "the test made me hate [reading and writing]. I didn't want to do it ever. I felt like, because I failed that I obviously suck at it. So I don't want to do something that I'm not good at" (Karlie, personal interview, June 10, 2009). Failing the test had a negative impact on Karlie's desire to engage with literacy practices on her own accord. Because of her OSSLT failure, she "felt ashamed. Every time I picked up a book or wrote something I felt disappointed just knowing I failed the literacy test. It was just a disappointment, and it reminded me of it" (Karlie, personal interview, June 10, 2009).

\section{Ontario Secondary School Literacy Course Completion}

When asked about how their reading and writing habits have changed since taking the OSSLC, the participants shared similar stories. Since her OSSLC enrollment, Laura stated that her reading and writing habits changed significantly:

Since I've taken the literacy course, I've been reading a lot more and actually taking notes and writing little blubs down. ... The test brought [my writing] down but the course really gave me a new view of it. Before I felt like I wanted to give up because I knew I couldn't meet their [Ministry] standards... then the course gave me the chance to know where my limits are and understand how far I could go and how I could push myself. (Laura, personal interview, June 10, 2009)

Andrew contended that his experience in the OSSLC gave him more confidence to read and write which, in turn, improved his reading and writing skill set:

I wasn't scared to read or scared to write anymore. I actually improved on increasing my paragraphs. I used to have two sentences; now I have five or six. I have a lot more to talk about now. (Andrew, personal interview, June 15, 2009)

For Karlie, knowing that after two failed attempts at the OSSLT she could take the OSSLC, gave her a sense of relief. She went on to say:

I see more of an importance in reading and writing, and that it's really valuable . . . I actually enjoy reading and writing now and before I couldn't stand it. The course made me love it $100 \%$ more. (Karlie, personal interview, June 10, 2009)

Karlie then spoke about how the OSSLC set her up for success, due in large part to all of the practice, stating that, "I am prepared to handle my work on my own" (Karlie, personal interview, June 10, 2009). She went on to say this about the OSSLC experience

Impacted all of my courses. It helped with everything. My average went up because of my ability to read and write better. It impacted my thoughts and learning things that are

Brock Education, 23(2), Spring 2014, pp.3-23 
new to me. I feel like I could pretty much do anything. (Karlie, personal interview, June 10, 2009)

Scott also spoke of how the OSSLC improved his beliefs about reading and writing, and how his skill set improved as a result of his enrolment and engagement in the course:

They [his beliefs] changed a little bit [after the OSSLC] because I now understand what I'm reading and I can put down what I'm thinking on a piece of paper. What I see in my head-I can jot notes down. The course helped me and it will help me in my apprenticeship. (Scott, personal interview, June 15, 2009)

\section{Relationship Building}

When asked what his feelings were during the first week of the literacy course, Andrew highlighted the nervousness and insecurity echoed by the other participants; however, he also clearly identified the importance of relationship building on the part of the classroom teacher, and how important that was for stimulating an environment of trust and teamwork, camaraderie and support.

I was kind of feeling nervous and scared that the teacher would actually make me go up there and read something right away, or that she'd laugh at my writing, or actually one of the kids would laugh at me. But then I realized that we were all there because of that reason and the teacher was there to help us. And I feel like everybody helped each other and we all took over our fears together. We all accomplished our work together. We worked as a team. (Andrew, personal interview, June 15, 2009)

Karlie cited two things for a newfound confidence and skill set: having a caring teacher teach the OSSLC and the course itself. When asked why this helped her, she stated,

I found that because my teacher liked doing what she was doing, she was able to help me more. That combined with all the strategies we learned in the course-brainstorming work, how tos (sic), taking a big assignment and breaking it down, reflecting and thinking about what we need to do, what we need to work on, and what we're good at-I took all of those things and began to write well. My teacher didn't get frustrated when I asked her a question. I could ask her as many times as I needed to and if I didn't get something she would just try to help me understand it no matter how much time it took. (Karlie, personal interview, June 10, 2009)

Karlie credits this relationship and the fact that her teacher was both caring and compassionate while demonstrating an interest in improving her skills, and in turn her self-confidence.

\section{Valuable versus Unimportant Experiences/Tasks}

Laura admitted that in grade 11, her first year as a senior, she began reading for fun as a way of self-improving her own literacy. She also mentioned that she "used to always like writing poems. It was all I did" (Laura, personal interview, June 10, 2009). This is an experience, a writing 
experience that is joyful for Laura because "you can just put your feelings down" (Laura, personal interview, June 10, 2009). Laura is just one student from this study who prefers expressive versus prescriptive writing. Andrew is another; he frequently writes for leisurely and social purposes, choosing poetry as his preferred method of expression.

Andrew credited the OSSLC with showing him that reading could be fun. When asked about his reading practices, he stated that he "never read before or after the test because I didn't like reading ... . Now I read outside of class and I actually find books interesting" (Andrew, personal interview, June 15, 2009). These activities, which observably make Andrew happy and jovial even in our conversation about them, demonstrate the positive and personally productive nature of what he views to be valuable literacy tasks. However, Andrew's experiences with literacy in school have not all been positive. He points out that, upon failing the OSSLT, the services offered by his high school were counterproductive: "The second time [the school offered to help]. So then I missed other classes and I had to catch up in them so it wasn't really worth going [to the tutorials]" (Andrew, personal interview, June 15, 2009). Scott, too, agreed that the services offered were superficial:

They got me a tutor and it didn't help me very much. It wasn't a very good experience. The tutor was [also] a student... but he didn't show up. I only had two or three sessions. I was in grade 10. The tutor was in grade 12 - a male - who received volunteer hours. (Scott, personal interview, June 15, 2009)

He reinforced the fact that the sessions "didn't really help me" (Scott, personal interview, June $15,2009)$ and, based on his facial expressions and body language, made it clear that these experiences were less than pleasurable.

For Karlie, the prescribed content of the test itself made the OSSLT an unimportant exercise. She stated, "I didn't like how the topics were chosen for you. I like more of a variety of what I get to write about" (Karlie, personal interview, June 10, 2009). Like Andrew, Karlie is more stimulated by expressive writing tasks and "topics that I like" (Karlie, personal interview, June 10, 2009).

The freedom to read and write was another noteworthy point that was brought up by several participants, including Karlie. She made the distinction between force and freedom: "Here [at school] you're forced to [read and write]. [Laughs.] And here it's strict, like there's a certain way to do things, like how to write and read. And at home, it's your own way. You choose what you do" (Karlie, personal interview, June 10, 2009). It is this very element of force and control, embodied within standardized testing that generates seemingly unimportant experiences with literacy for young people. Given the opportunity to exercise more freedom with her literacy skills development, Karlie said she would "pick what I'd want to read and what I want to write about" (Karlie, personal interview, June 10, 2009).

When asked what type of writing Karlie engaged in after school, she said, "I write journals and short stories" (Karlie, personal interview, June 10, 2009). In Karlie's words, she would write journals and short stories,

Because I can relate them to myself. If you're writing an essay or a news article, it's kind of pointless. There's no reason really. It's a deadly experience. [Laughs.] It's not fun and it's not enjoyable. It's sometimes aggravating, especially when teachers say it has to be a 
certain length and you can't get it to be that length without repeating yourself. I hate that. (Karlie, personal interview, June 10, 2009)

In this statement, another key point is raised: the inherent value in making a connection between skills taught, skills learned, and skills used. Students must feel invested in a task to take it seriously. There must be some sort of transferable skill and practical application, at least in Karlie's view.

\section{Literacy and Identity}

\section{Self-Esteem}

The participants recalled how they felt after OSSLT results. Laura, a student who sets high standards for herself, admitted that she felt shocked:

I was really shocked like... I was kinda (sic) disappointed cause I thought I did better but I guess it wasn't to "their standards"... I guess they were thinking that my standards were poor. (Laura, personal interview, June 10, 2009)

Karlie shared the same sentiment. When she found out she did not pass the test, she felt "sad, disappointed, angry. I felt stupid" (Karlie, personal interview, June 10, 2009). For Karlie, these feelings do not align with how she sees herself: "I see myself as being smart, out-going, and fun" (Karlie, personal interview, June 10, 2009). Her standardized test failure did not align with her perception of self. For Karlie, her self-esteem dropped as a result of the OSSLT, which caused her to view herself differently and increase her awareness of how others might view her. By the end of grade 10, Karlie revealed that she viewed herself and her abilities differently.

I felt a lower self-esteem and I didn't feel like I could be good in any subject. I felt like reading and writing is a very big part of education, and that if I wasn't successful in literacy I wasn't going to be successful in any other course. (Karlie, personal interview, June 10, 2009)

Interestingly enough, in her grade 12 year, Karlie did not tell her friends/peer group that she was taking the OSSLC. She spent the semester covering up the truth and claiming she was heading to a "regular" English class. When asked why she had this concealment, she stated, "cause I was embarrassed. I felt like they would think I was stupid, too" (Karlie, personal interview, June 10, 2009). Despite the fact that Karlie verbalized her confidence, there is a clear image of a girl who was left feeling insecure after her standardized test failure. For her, having her friends know "the truth" would only confirm what she was feeling inside. During the first week of the course, Karlie admitted that she,

felt stupid, and really shy. I didn't want to raise my hand for anything. I didn't really want to talk because I felt like if I did my teacher would notice my lack of ability right away, and I didn't want to how her that I was incapable of doing anything. I was afraid that she and the students would judge me. I thought maybe a lot of kids said that "I only failed by one" and "I only failed because I couldn't go cause I was sick and couldn't

Brock Education, 23(2), Spring 2014, pp.3-23 
write the test." I felt like maybe students would say "she failed by a lot cause she can't do this." I thought that people might stereotype kinda. (Karlie, personal interview, June 10, 2009)

When asked what this stereotypical OSSLC student is like, she replied: "Well, you think that they'd be like dumb or . . . just quiet, and not outgoing. Different. Weird. Not like everybody else" (Karlie, personal interview, June 10, 2009). She continued, "I was afraid of people thinking that I'm stupid. That's the worst feeling, to have someone think that they're better than you" (Karlie, personal interview, June 10, 2009).

Like Karlie, Laura feared judgment due to her OSSLC enrollment. During the first week of the course, Laura admitted,

I was actually really nervous. [Laughs.] I was actually scared cause I always thought that everyone around me was going to be like "Oh, she's in literacy. Look at her, she's in literacy," but everyone was really welcoming and it was fun and I learnt a lot and I was actually glad I took it and didn't wait till this year to write [the OSSLT] again. (Laura, personal interview, June 10, 2009)

By the end of the course, Laura was more optimistic and positive about her personal achievement. Personal, rather than provincial, standards became the focus.

The fact that I would always try to push myself to meet everyone in the class, always try to compete with them and be like "I could beat this," "I could do that" and then I think the positive thing is knowing that I know where I stand and I don't have to try and meet their expectations. I just have to do it for myself. (Laura, personal interview, June 10, 2009)

Unlike Laura and Karlie, Andrew was not surprised to receive word that he had not successfully completed the OSSLT: "I wasn't shocked. I wasn't shocked. I'm not a good writer or reader or speaker for that matter. I knew I was going to do bad on it" (Andrew, personal interview, June 15, 2009). It is clear by this response that Andrew defined "good" as passing the OSSLT. His definition of success was a narrow vision dictated by standardized testing. This is, in short, is how Andrew perceived himself in relation to, and in his relationship with, literacy. He credited the OSSLC with giving him more confidence to read and write, thereby improving his skill set and his self-esteem, which he says increased dramatically. Andrew stated: "I have a lot more confidence in myself now. I'll actually volunteer [to read and write in front of the class]" (Andrew, personal interview, June 15, 2009). Andrew credited the course with improving his self-esteem and thinks that it would be beneficial for all students.

\section{Self-Efficacy}

For the purpose of this study, self-efficacy, although a concept related to self-esteem, referred to the belief in one's ability (Bandura, 1977). All of the participants involved in this study found that the OSSLC greatly enhanced their self-efficacy; despite the fact that the OSSLT made them believe that their skills were substandard. While some participants, like Andrew, were not surprised to find out they were unsuccessful on the OSSLT, others, like Karlie, were devastated

Brock Education, 23(2), Spring 2014, pp.3-23 
to learn that their literacy performance on this standardized test did not align with how they viewed their literacy abilities. Each participant shared the same sentiment: that enrolment in and completion of the OSSLC enhanced their belief in their abilities.

\section{Discussion and Recommendations}

\section{Teachers}

Teachers need to be comfortable addressing matters of literacy in all subject areas with adequate expertise, training, and a confident grasp of the literacy needs of each learner (Fairbairn \& Fox, 2009). An inclusive conception of literacy is needed within classrooms, along with some typically elementary-based literacy strategies (Kearns, 2011). Traditional elementary school strategies like elements of a balanced reading program (e.g., teacher-modeling and guided reading and writing) have proven to be effective with adolescent literacy learners in the secondary setting (Lewis \& Wray, 2001; Van De Wal, 2010; Wilhelm, 2001). These strategies help to stress reading and writing as process, which is particularly important since "learning how to do things is especially important for at-risk students" (Wilhelm, 2001, p. 34).

Enhanced self-efficacy is the first step to literacy improvement for the struggling student (Margolis \& McCabe, 2006). Through the foundation of trust, the teacher-leader can motivate and encourage students, and the students know that their best interests are in mind. The role of the teacher, then, becomes that of coach and cheerleader. Having a teacher who is enthusiastic and excited about the learning helped to encourage one student in particular to be more engaged in her own learning. Working with a role model can empower the student because it helps to establish community and bonds (Corkery, 2005).

Lastly, for the adolescent literacy learner, authenticity and personal relevance was paramount, as Wilhelm (2001) explained that these "readers need a personally relevant and socially significant purpose" (p. 34) in order for motivation to bloom. Thomas (2001) explained that "student reading is authentic when it involves reading for student understanding and reading for pleasure. Authentic writing includes writing to understand, and writing for self-expression, with a premium placed on student choice" (p. 65). However, "many at-risk students are particularly alienated by school until teachers value what they already know . . . and help them put those skills to work" (Wilhelm, 2001, p. 34).

\section{Schools}

Irvin et al. (2007) claimed that adolescent literacy development was neglected in secondary schools, stemming from a lack of understanding when it comes to the complex nature of literacy learning and a lack of training to support students' literacy development, despite higher literacy demands than ever before. Beyond identifying adolescent literacy as a school-wide problem, regardless of a teacher's subject specialty, secondary schools should take measures to target learners that require additional support with literacy upon entry into high school. Most often in past learning experiences students received support with literacy after a poor performance on an OSSLT pre-test, or in preparation to write the OSSLT a second time.

Another way to support teachers is to allow for both formal and informal leadership and collaboration (Ryan \& Soehner, 2011). While formal leadership may take the form of a school-

Brock Education, 23(2), Spring 2014, pp.3-23 
wide literacy committee, informal leadership may be an interested teacher sharing success stories with staff members; offering support, strategies, or resources to peers; or modeling effective literacy instruction to an interested teacher or group (Ryan \& Soehner, 2011). Whatever the approach, the promotion of literacy as a secondary school culture "topic of interest," whether formally or informally, is a beneficial way to generate involvement and excitement surrounding the issue.

\section{School Boards}

The involvement of senior administration is essential to the success of individual schools in implementing literacy initiatives (Lewis \& Wray, 2001). Because secondary school teachers are often not trained in literacy instruction, school boards should strive to offer programs or workshops to assist classroom teachers in becoming competent literacy teachers with a repertoire of strategies (Fairbairn \& Fox, 2009). This type of teacher training must also include a consideration of the social, emotional, and psychological impacts of repeated failure or poor literacy skills, particularly for the adolescent learner, so that educators may be equipped to create a safe and positive classroom environment in which the adolescent literacy learner may feel most comfortable (Ryan \& Soehner, 2011). School boards can enhance support for teacher training by allocating a position as school literacy coach.

\section{Conclusion}

While the majority of participants were adversely affected-academically, emotionally, socially, and psychologically - by their standardized test failure, all of the participants recognized an important purpose or function of the OSSLC. While initially the participants had reservations about the course, by the end of their experience in the OSSLC, all participants felt more confident in their abilities and appreciated the opportunity to engage in a unique process (ethnographic study), despite the fact that this occurred during their last year of high school. The ethnographic study provided a detailed day-to-day picture of events and captured the culture of the students as a group with shared values, language, and beliefs over time (Creswell, 2012).

In Ontario schools, there is a divide between measuring literacy achievement and providing appropriate and timely interventions for struggling learners. While each individual classroom teacher works with his or her students to meet expectations outlined in curriculum documents or the student's IEP, we know that students may enter high school without having the prior knowledge or skills necessary for success on the OSSLT. Given this disconnect between what students may be expected to know in order to graduate elementary school and the skills students are expected to demonstrate on a high-stakes standardized test in order to graduate from high school, the current system is not setting students up for success. These students, then, view the OSSLT as punitive rather than productive, as a test they are forced to write even if they are not adequately prepared to do so. Beyond the hurt and embarrassment felt by unsuccessfully completing the test, these students are genuinely struggling with some aspects of traditional, school-based literacy and require appropriate interventions beyond simple tutorials that teach to the OSSLT.

We agree that early intervention, even a research-based intervention in grade 9, must occur. The participants of this study repeatedly stated that receiving appropriate support and assistance in the OSSLC and setting goals for personal success were significant aspects that lead

Brock Education, 23(2), Spring 2014, pp.3-23 
to personal triumph. They highlighted the importance of a caring teacher who saw value in the work being done and acted as a cheerleader or coach. Valuable tasks were ones that provided choice, allowed them to feel invested, and were authentic given their interests, talents, and skills. As schools and teachers continue to move toward a student-centered approach, the student voice will be increasingly celebrated.

As more emphasis is put on student success at the secondary school level, it will become increasingly important to include the student experience, his or her perceptions and voice, in order to determine what will truly assist these learners. A vision for literacy at the secondary school level needs to take place independent of EQAO results and Ontario Ministry of Education visions for students in Ontario in order for the interest to be genuine and the results to be authentic and meaningful. Diligent, caring, and compassionate classroom teachers are the most effective tool for helping adolescent learners increase their engagement and achievement with respect to literacy. Administrators and school boards must provide the professional development necessary to support secondary teachers who may not come with a wealth of experience in teaching basic literacy skills.

If we can implement strategies to combat insecurities, build the self-esteem of our students, engage adolescents in literacy activities beyond the walls of the classroom, and celebrate the varying levels of success in our students, we will truly assist these learners in a holistic way that respects their abilities while encouraging positive, productive, and authentic growth.

Brock Education, 23(2), Spring 2014, pp.3-23 


\section{References}

Agee, J. (2009). Developing qualitative research questions: A reflective process. International Journal of Qualitative Studies in Education, 22(4), 431-447.

Alvermann, D. (2001). Reading adolescents' reading identities: Looking back to see ahead. Journal of Adolescent and Adult Literacy, 44(8), 676-690.

$\mathrm{Au}, \mathrm{W}$. (2009). Unequal by design: High-stakes testing and the standardization of inequality. New York: Routledge, Taylor and Francis.

Bandura, A. (1977). Self-efficacy: Toward a unifying theory of behavioural change. Psychological Review, 84(2), 191-215.

Beth, A. D., Reed, J. H., Schallert, D. L., \& Woodruff, A. L. (2004). Motivated reader, engaged writer: The role of motivation in the literate acts of adolescents. In J. A. Dole \& T. L. Jetton (Eds.), Adolescent literacy research and practice (pp. 251-282). New York, NY: Guilford Press.

Bouchard, D. (2003). Improve student literacy: Pick up a book and read. Teacher Librarian, $30(3), 63$.

Brozo, W., \& Simpson, M. (1991). Readers, teachers, learners: Expanding literacy across the content areas (3rd ed.). Upper Saddle River, NJ: Merrill.

Casey, H. K. (2008). Engaging the disengaged: Using learning clubs to motivate struggling adolescent readings and writers. Journal of Adolescent and Adult Literacy, 52, 284-294.

Corkery, C. (2005). Literacy narratives and confidence building in the writing classroom. Journal of Basic Writing, 24(1), 48-67.

Creswell, J. W. (2008). Educational research: Planning, conducting, and evaluation quantitative and qualitative research (3rd ed.). Upper Saddle River, NJ: Pearson.

Creswell, J. W. (2012). Educational research: Planning, conducting, and evaluation quantitative and qualitative research (4th ed.). Upper Saddle River, NJ: Pearson.

Dillon, D. R., Moje, E. B., \& O’Brien, D. (2000). Reexamining roles of learner, text, and context in secondary literacy. The Journal of Educational Research, 93(3), 165-180.

Education Quality and Accountability Office. (2011). EQAO tests in secondary school: A guide for parents and students. Retrieved from www.eqao.com

Brock Education, 23(2), Spring 2014, pp.3-23 
Fairbairn, S. B., \& Fox, J. (2009). Inclusive achievement testing for linguistically and culturally diverse test takers: Essential considerations for test developers and decision makers. Educational Measurement: Issues and Practice, 28(1), 10-24.

Freire, P. (1970). Pedagogy of the oppressed. (M. Bergman Ramos, Trans.). New York, NY: The Seabury Press.

Freire, P., \& Macedo, D. (1987). Literacy: Reading the word and the world. London, England: Bergin \& Garvey.

Gee, J. P. (1996). Social linguistics and literacies: Ideology in discourses (2nd ed.). London, England: Falmer.

Graham, C., \& Neu, D. (2004). Standardized testing and the construction of governable persons. Journal of Curriculum Studies, 36(3), 295-319.

Hall, L. A. (2012). Rewriting identities: Creating spaces for students and teachers to challenge the norms of what it means to be a reader in school. Journal of Adolescent \& Adult Literacy, 55(5), 368-373.

Hinchman, K. A., \& Moje, E. B. (1998). Locating the social and political in secondary school literacy. Reading Research Quarterly, 33(1), 117-128.

Irvin, J. L., Meltzer, J., \& Dukes, M. (2007). Taking action on adolescent literacy: An implementation guide for school leaders. Alexandria, VA: Association for Supervision and Curriculum Development.

Jeong-Hee, K. (2011). Narrative inquiry into (re)imagining alternative schools: A case study of Kevin Gonzales. International Journal of Qualitative Studies in Education, 24 (1), $77-$ 96.

Johnston, P. H., \& Winograd, P. N. (1985). Passive failure in reading. Journal of Literacy Research, 17(4), 279-301.

Kamil, M. L., \& Kim, H. S. (2004). Adolescents, computer technology, and literacy. In J. A. Dole \& T. L. Jetton (Eds.), Adolescent literacy research and practice (pp. 351-378). New York, NY: Guilford Press.

Kearns, L. (2011). High-stakes standardized testing and marginalized youth: An examination of the impact on those who fail. Canadian Journal of Education, 34(2), 112-130. Retrieved from http://www.freepatentsonline.com/article/Canadian-JournalEducation/271594486.html

Klinger, D., \& Luce-Kapler, R. (2007). Walking in their shoes: Students' perceptions of largescale high-stakes testing. Canadian Journal of Program Evaluation, 22(3), 29-52.

Brock Education, 23(2), Spring 2014, pp.3-23 
Klinger, D., Rogers, W. T., Anderson, J., Poth, C., \& Calman, R. (2006). Contextual and school factors associated with achievement on a high-stakes examination. Canadian Journal of Education, 29(3), 771-797.

Lewis, M., \& Wray, D. (1999). Secondary teachers' views concerning literacy and literacy teaching. Educational Review, 51(3), 273-280.

Lewis, M., \& Wray, D. (2001). Implementing effective literacy initiatives in the secondary school. Educational Studies, 27(1), 45-54.

Luttrell, W., \& Parker, C. (2001). High school students' literacy practices and identities, and the figured world of school. Journal of Research in Reading, 24(3), 235-247.

Main, K. L. (2008). Teaching beyond the test: The possibility of success. English Journal, 97(5), 46-51.

Margolis, H., \& McCabe, P. P. (2006). Motivating struggling readers in an era of mandated instructional practices. Reading Psychology, 27, 435-455. doi:10.1080/02702710600848023

Maxwell, J. (2010). It's time to reboot education for adults with low literacy skills. Retrieved from http://tamarackcommunity.ca/downloads/index/Time_to_Reboot.pdf

McNeil, L. (2000). Contradictions of school reform: Educational costs of standardized testing. New York, NY: Routledge.

Moje, E. B. (1996). "I teach students, not subjects": Teacher-student relationships as contexts for secondary literacy. Reading Research Quarterly, 31(2), 172-195.

Moje, E. B. (2002). Re-framing adolescent literacy research for new times: Studying youth as a resource. Reading Research and Instruction, 41(3), 211-228.

Moje, E. B., Young, J. P., Readence, J. E., \& Moore, D. W. (2000). Reinventing adolescent literacy for new times: Perennial and millennial issues. Journal of Adolescent \& Adult Literacy, 43(5), 400-410.

Moon, T. R., Brighton, C. M., Jarvis, J. M., \& Hall, C. J. (2007). State standardized testing programs: Their effects on teachers and students (RM07228). Storrs, CT: The National Research Center on the Gifted and Talented, University of Connecticut.

Movement for Canadian Literacy. (2005). A 10-year, results-based national literacy action plan, 2006-2016. Retrieved from http://www.nald.ca/library/research/10year/tenyear.pdf

Nezavdal, F. (2003). The standardized testing movement: Equitable or excessive? McGill Journal of Education, 38(1), 65-78.

Brock Education, 23(2), Spring 2014, pp.3-23 
O'Brien, D. G. (1998). Multiple literacies in a high school program for "at-risk" adolescents. In D. E. Alvermann, K. A. Hinchman, D. W. Moore, S. F. Phelps, \& D. R. Waff (Eds.), Reconceptualizing the literacies in adolescents' Lives (pp. 27-49). Mahwah, NJ: Erlbaum.

O’Brien, D. G., Stewart, R. A., \& Moje, E. B. (1995). Why content literacy is difficult to infuse into the secondary curriculum: Strategies, goals, and classroom realities. Reading Research Quarterly, 30, 442-463.

Ontario Ministry of Education. (2009). Policy/program memorandum no. 127. Toronto, ON: Queen's Printer for Ontario.

Pahl, K., \& Rowsell, J. (2005). Literacy and education: Understanding the new literacy studies in the classroom. Thousand Oaks, CA: Sage.

Ricci, C. (2004). The case against standardized testing and the call for a revitalization of democracy. The Review of Education, Pedagogy, and Cultural Studies, 26(4), 339-361.

Ryan, T. G. (2003). Reflections of a provincial achievement test marker and scorer. In Passing the test: A book of readings on provincial, national and international testing in Canadian public schools. Ottawa, Ontario.

Ryan, T.G., \& MacGregor, C. (2011). Secondary level reentry of young adult learners: A case study. Australian Journal of Adult Learning, 51 (1), 143-160.

Ryan, T.G., \& Soehner, D. (2011). School leadership and student achievement. The ScholarPractitioner Quarterly, 4(2), 24-48.

Statistics Canada. (2005). Building on our competencies: Canadian results of the international adult literacy and skills survey, 2003. Retrieved from http://www.statcan.gc.ca/pub/89617-x/89-617-x2005001-eng.pdf

Statistics Canada. (2008). Literacy skills of Canadians across the ages: Fewer lower achievers, fewer high achievers. Retrieved from http://www.statcan.gc.ca/pub/81-004x/2007006/article/10528-eng.htm

Street, B. V. (1994). Cross-cultural perspectives on literacy. In J. Maybin (Ed.), Language and literacy in social practice: A reader (pp. 139-150). Clevedon, England: Multilingual Matters.

Sweet, M. E. (2006). Standardized testing - Unmasking a threat to democracy. Munich, Germany: GRIN Verlag.

Taylor, R., \& Doyle Collins, V. (2003). Literacy leadership for grades 5-12. Alexandria, VA: Association for Supervision and Curriculum Development.

Brock Education, 23(2), Spring 2014, pp.3-23 
Taylor, S. V., \& Nesheim, D. W. (2000). Making literacy real for "high-risk" adolescent emerging readers: An innovative application of readers' workshop. Journal of Adolescent and Adult Literacy, 44, 308-318.

Thomas, P. L. (2001). Standards, standards everywhere, and not a spot to think. The English Journal, 91(1), 63-67.

Vacca, R. T. (1998). Foreward. In D. E. Alvermann, K. A. Hinchman, D. W. Moore, S. F. Phelps, \& D. R. Watt (Eds.), Reconceptualizing the literacies in adolescents' lives (pp. xv-xvi). Hillsdale, NJ: Erlbaum.

Van De Wal, L. (2010). Using balanced literacy with adolescent literacy learners (Unpublished action research project). Nipissing-Parry Sound Catholic District School Board, Ontario, Canada.

Van De Wal, L. (2012). Student perceptions of literacy after the Ontario Secondary School Literacy Course: A qualitative inquiry (Unpublished master's thesis). Nipissing University, North Bay, Ontario.

Volante, L. (2006). Toward appropriate preparation for standardized achievement testing. Journal of Educational Thought, 40(2), 129-144.

Wilhelm, J. (2001). Getting kids into the reading game: You gotta know the rules. Voices from the Middle, 8(4), 25-36.

Zheng, Y., Klinger, D.A., Cheng, L., Fox, J., \& Doe, C. (2011). Test-takers' background, literacy activities, and views of the Ontario Secondary School Literacy Test. Alberta Journal of Educational Research, 57(2), 115-136. 